Богом'я В.І., Давидов В.С., Доронін В.В., Кудрявцев В.Г.

\title{
АЛГОРИТМ АВТОМАТИЗОВАНОГО КОНТРОЛЮ ПОЛОЖЕННЯ КІНЦІВОК СУДЕН І СКЛАДІВ НА ТРАЕКТОРІЇ РУХУ ЗАСОБАМИ ЕСDIS
}

У статті розглянуто алгоритм контролю положення суден і складів на траєкторії руху, якій вирішує проблему автоматизованого високоточного контролю положення кінцівок суден $i$ складів на траєкторї руху засобами ECDIS. Створений алгоритм автоматизованого контролю положення кінцівок суден і складів на траєкторії руху, шляхом використання координатного курсора ECDIS в якості високоточного кутомірнодалекомірного пристрою, дозволяє, при розміщенні в носі і кормі судна антен приймачів ГНСС, сформувати на ЕК їх електронні позначки зі своїми координатними курсорами. Ці курсори можливо використовувати, при реалізачії автоматичного, за допомогою циифрових слідячих систем захоплення (до повного збігання кодів координат) $і$ супруводження їх кінцамі контролюемих об'єктів (географічні коордінати яких знаходяться в електронної базі даних) для високоточного автоматичного вимірювання пеленгів $i$ дистаниій до підводних i надводних небезпек в режими “оп-line” в иілях контролю за їх допомогою положення кінцівок суден та складів відносно небезпек з точністю порівняної з точністю роботи ГНСС в спеціальних режимах. Експериментальні дослідження, які були проведені иляхом комп'ютерного імітаціонного моделювання, підтвердили високу очікувану точність роботи запропонованого алгоритму, якій базується на однойменному способі.

Ключові слова: алгоритм, судно, спосіб, автоматизований контроль, координатний курсор, пеленг, дистаниія, безпека плавання, траєкторія руху.

Постановка проблеми. Аналіз аварійних морських подій великотоннажних суден та складів, які пов'язані з посадками на мілину і торканнями грунту, навалами на інші судна $\mathrm{i}$ гідротехнічні споруди та причали свідчать про те, що тих рівнів безпеки, які існують в даний час 3 використанням суднових і берегових систем, у тому числі ECDIS 3 існуючими функціями безпеки, недостатньо для надійного забезпечення навігаційної безпеки плавання.

Найбільшу небезпеку для судноплавства в прибережній зоні представляють підводні рифи та інші малорозмірні підводні небезпеки, які не можуть бути виявлені радіолокаційними системами взагалі і на безпечній дистанції за допомогою існуючіх ехолотів. Незнання відстаней до них від кінцівок суден і складів 3 необхідною точністю, при плаванні в безпосередній близькості, призводить до зіткнення з ними суден і іноді подальшої загибелі від затоплення або перекидання. В зв'язку з цим необхідна розробка додаткових заходів щодо підвищення навігаційної безпеки плавання суден і складів в прибережній зоні, на акваторіях гаваней і портів.

Мета роботи. Розробка алгоритму автоматизованого контролю положення кінцівок суден і складів на траєкторії руху засобами ECDIS.

Виклад основного матеріалу досліджень. Райони прибережного плавання, обмежені умови гаваней i портів, які характеризуються відносно малими глибинами і великою інтенсивністю судноплавства є місцем переважної кількості тяжких аварій і загибелі суден. Аналіз таблиці1 [4] показує, що друге місце за кількістю аварійних морських подій займають посадки суден на мілину, які як правило $є$ наслідком значних похибок у визначенні місця розташування судна щодо навігаційних небезпек. Найбільш явно ця проблема проявилася у 2012 р при зіткненні з підводними рифами в жовтні місяці контейнеровоза «Рена» поблизу Нової Зеландії і в січні пасажирського суперлайнера «Коста-Конкордія» в Тіренском море в прибережній зоні Італії.

Поява на морських та річкових суднах ECDIS і приймачів ГНСС, які дозволили в значній мірі автоматизувати високоточній контроль за місце розташуванням суден на траєкторії руху 
в режими “on-line”, не привела до значного зниження аварійності, пов'язаної з посадками на мілину або підводні рифі, зіткненнями і навалами. Використання функцій: «завдання безпеки» [1], «виявлення поточної небезпечної ізобати і небезпечних об'єктів» [2], а також «автоматичного захоплення і супроводу цілей при накладенні зображення РЛС на ЕК» $[1,2]$ в існуючих ECDIS, які використовуються при проводці суден та складів в каналах і на акваторіях портів і гаваней не вирішує в повній мірі завдання безпечного плавання в складніх умовах. Цьому сприяють такі об'єктивні чинники, як:

1.Невідповідність габаритів існуючих каналів i фарватерів габаритам сучасних великотоннажних суден і складів, які в багатьох портах світу і на підходах до них обмежені своєю осадкою і розмірами. Це призводить, при плаванні на мілководді, до погіршення керованості і збільшення радіусів циркуляції, які не завжди підлягають точному обліку при плаванні на циркуляції і як наслідок вихід однієї з кінцівок судна за межі смуги руху, що стає причиною торкань грунту і посадок на мілину.

2. Вплив на безпеку плавання конструктивних особливостей суден i ïx маневрених характеристик, закладених на стадії проектування:

- великотоннажнисть суден визначає довгий гальмівний шлях як при пасивному так i активному гальмуванні, який становить тисячі метрів i через відсутність на суднах високоточних автоматичних вимірювачів дистанцій до навігаційних небезпек, особливо підводних, в достатній мірі не контролюється;

- значна частина сучасних суден $є$ одновальной, що негативно позначається на їх маневреності та повороткості і 3 урахуванням дуже великий парусністі, особливо контейнеровозів, автомобілевозів і газовозів, призводить до того, що часом при сильному вітрі не вистачає зусиль вінторульового комплексу для утримання суден в заданій смузі на траєкторії руху або на лінії створу.

3. Суднові системи безпеки у вигляді ехолотів, РЛС і ECDIS також мають обмеження в своїх можливостях і за своїми технічними характеристиками не в змозі гарантовано забезпечувати безпеку плавання в будь-яких умовах і районах:

навігаційнї ехолоти не в змозі завчасно інформувати судноводіїв про небезпеки поблизу різких підняттів дна у вигляді рифів, одиночних банок або затонулих великогабаритних об'єктів, так як вони вимірюють глибину тільки під кілем судна в місці установки вібраторів; - РЛС, при точності вимірювання дистанцій в 3\% від використовуваної шкали і пеленга в 1 \%, при плаванні поблизу берегів з низькою відбивною здатністю, також не в змозі забезпечити необхідну [4] точність визначення координат місця судна;

- в суднових ECDIS не в повній мірі використовуються можливості високоточного місця судна по ГНСС, що працюють в спеціальних режимах, (точність яких порівнянна з точністю масштабу електронної карти) для коригування траєкторії руху судна по пеленгам i дистанціям на підводні і надводні навігаційні небезпеки від свого високоточного місця в автоматичному «on - line» режимі.

Інформація, яка наведена в табл. 1 виконана Токійським інститутом морського флоту за період з 2002 по 2008 рік., свідчить про те, що при плаванні в прибережній 3-х мильній зоні за 7 років в світовому флоті 469 суден стали учасниками посадок на мілину і зіткнень[4]. На кінцівки суден при цьому доводиться 55\% випадків від загальної кількості АМП [3], тобто ніс і корма $\epsilon$ найбільш вразливими частинами корпусу судна, особливо у великогабаритних суден та складів $[10,11]$.

Проблема полягає в відсутності практично на всіх суднах торговельного і пасажирського флоту високоточних засобів для автоматичного контролю положення носа і корми судна на траєкторії руху відносно підводних навігаційних небезпек, що вкрай важливо при плаванні на мілководді і поблизу рифів. Вимоги до точності судноводіння в залежності від району плавання наведені в таблиці 2 [4].

Комплексне використання можливостей ECDIS та системи рознесених в кінцівки судна антен приймачів ГНСС дозволяє вирішити цю задачу. Для цього необхідно автоматизувати в ECDIS процес автоматичної координатної прив'язки, захоплення і супроводу кінцями рухливих координатних курсорів, що виходять з високоточних позицій носа і корми судна на електронній карті (ЕК) навігаційних орієнтирів, що мають високоточну геодезичну основу i координати яких внесені в електронну базу ECDIS. При точному збігу координат 
навігаційних орієнтирів 3 координатами кінців координатних курсорів судноводій отримує 3 досить високою точністю положення носа і корми свого судна на траєкторії руху і буде в змозі контролювати їх положення по пеленгам і дистанціям відносно орієнтирів або навігаційних небезпек в режимі «on-line».

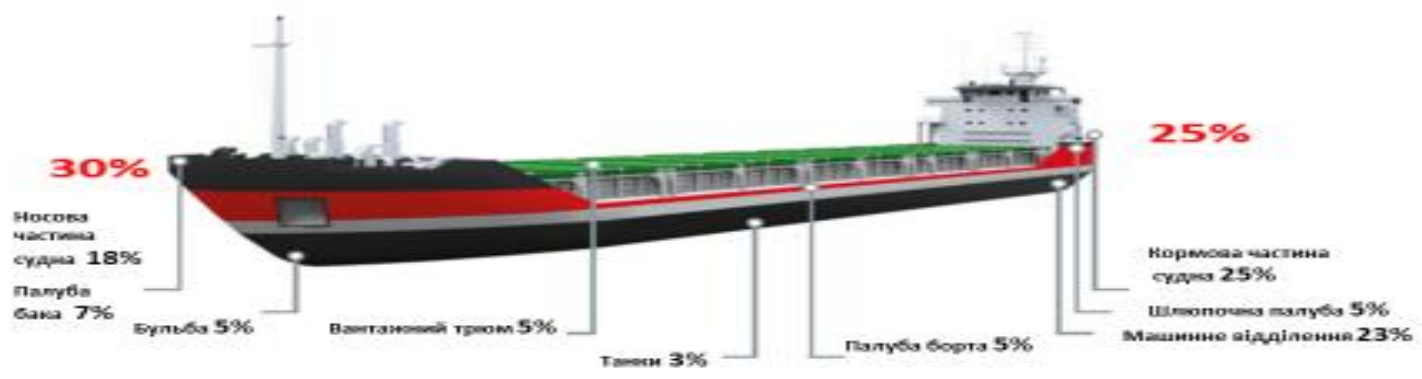

Рис.1 Розподіл наслідків АМП по частинах корпусу судна

Таблиця 2

Стандарти точності судноводіння

\begin{tabular}{|l|c|}
\hline \multicolumn{1}{|c|}{ Район плавання } & Гранична точність координат (P=95\%), м \\
\hline Акваторії портів & 1 \\
\hline Прибережні води & 10 \\
\hline Обмежені води & 10 \\
\hline Внутрішні водні шляхи & 10 \\
\hline Моря і океани & $10-100$ \\
\hline
\end{tabular}

Відомий спосіб відображення позиції судна на ЕК по даним ГНСС в виді єдиної позначки, яка відповідає розташуванню антени приймача ГНСС, не в повної мірі реалізує можливості ECDIS i в умовах неможливості точного обліку інерційно- гальмівних характеристик та елементів повороткості, не дозволяє вирішити в повної мірі проблеми безпечного судноводіння в складних умовах плавання [5,9,11]. Відмінною особливістю даного алгоритму, від застосовуваних раніше, $\epsilon$ те, що контроль знаходження судна на траєкторії руху відбувається 3 урахуванням його положення відносно навігаційних небезпек по пеленгам і дистанціям від «себе», тобто від свого високоточного місця.

Найбільш близьким до пропонованого технічним рішенням, вибраним як прототип, $\epsilon$ використання функцій: «завдання безпеки» [1], «виявлення поточної небезпечної ізобати i небезпечних об'єктів» [2] в існуючих ECDIS, а також автоматичного захоплення і супроводу цілей в ЗАРП. В основу алгоритму, що розробляється, поставлено завдання створити алгоритм автоматизованого контролю положення кінцівок суден і складів на траєкторії руху, шляхом використання координатного курсора в якості високоточного кутомірнодалекомірного пристрою, який дозволяє, при розміщенні в носі і кормі судна антен приймачів ГНСC GPS і ГЛОНАСС, сформувати на ЕК їх електронні позначки зі своїми координатними курсорами. Ці курсори можливо використовувати, при реалізації автоматичного, за допомогою цифрових слідячих систем (ЦСС), цифрового захвату їх кінцамі контролюемих об'єктів, географічні коордінати яких знаходяться в електронної базі даних ( до повного збігання кодів координат) для високоточного вимірювання пеленгів $\mathrm{i}$ дистанцій до підводних і надводних небезпек в режими “on-line" в цілях контролю за їх допомогою положення кінцівок суден та складів відносно небезпек з точністю порівняної 3 точністю роботи ГНСС в спеціальних режимах $[6,7,9]$.

Для вирішення поставленої задачі необхідно виконати розміщення антен ГНСС в кінцівках суден і відповідне доопрацювання програмного забезпечення ECDIS, яке дозволило б виробляти автоматичну прив'язку географічних координат кінців координатних курсорів к 
географічним координатам підводних та надводних небезпек і після їх високоточної кодової синхронізації відстежувати їх положення в процесі руху суден на заданій траєкторії, по аналогії з роботою автоматичного захоплення i супроводу цілей в ЗАРП. Суть запропонованого алгоритму полягає в тому, що в ECDIS йде постійне автоматичне порівняння поточних значень пеленгів і дистанцій на небезпечні об'єкти від позначок носової та кормової кінцівок суден на ЕК 3 їх заздалегідь встановленими на ЕК огороджувальними небезпечними дистанціями ДНБ. і пеленгами ПНБ на ці небезпечні об’єкти. При досягненні поточними значеннями Dнкі (Dккі), Пнкі (Пккі) небезпечних величин автоматично виробляються попереджувальні звукові і світлові сигнали. У разі відсутності на них реакції з боку вахтового помічника капітана або капітана судна, за ознаками відсутності маневру судна, яка може бути пов'язана з їх обмеженими фізичними можливостями або промахами в розрахунках і оцінки ситуації по інформації від інших менш точних засобів судноводіння, в ECDIS самостійно формуються виконавчі сигнали управління на засоби керування напрямком руху і рушії судна. Це призводить до завчасної автоматичної зміні курсу і (або) швидкості судна для безпечного проходження кінцівками судна навігаційних небезпек.

Вихідною інформацією блоків вироблення поточних значень дистанцій і пеленгів від носу і корми судна до небезпечних об'єктів є: поточні полярні координати небезпечних об'єктів

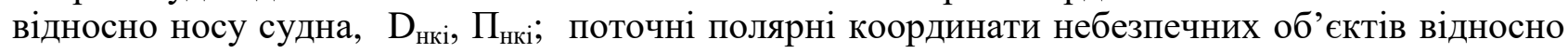
корми судна, $\mathrm{D}_{\text {ккі}, ~}$ ккі.

По поточним полярним координатам положення небезпечних об'єктів відносно носу і корми судна і завчасно, при плануванні рейсу, введеними в електронну базу ECDIS небезпечних значень дистанцій і пеленгів в блоці виконується постійний розрахунок відхилень поточних значень пеленгів і дистанцій від їх небезпечних значень

$$
\begin{gathered}
\Delta \text { Dнкі }=D_{\text {нкі }}-\text { ДНБ; } \\
\Delta \prod_{\text {нкі }}=\prod_{\text {нкі }}-\text { ПНБ; } \\
\Delta \mathrm{D}_{\text {ккі }}=\mathrm{D}_{\text {ккі }}-\mathrm{DHБ;} \\
\Delta \prod_{\text {ккі }}=\prod_{\text {ккі }}-\text { ПНБ. }
\end{gathered}
$$

При досягненні нерівностями (2) значень

$$
\text { DНБ } \geq \mathrm{D}_{\text {нкі }}, \text { ПНБ } \geq \Pi_{\text {нкі }} ; \text { DНБ } \geq \mathrm{D}_{\text {ккі }}, \text { ПНБ } \geq \Pi_{\text {ккі }},
$$

в блоці формування сигналів і команд виробляються: попереджувальні звукові і світлові сигналі про небезпеку; сигнал виклику капітана на ходовий місток; керуючі сигналі на гвинторульової комплекс.

Використання полярних координат для контролю безпечного проходження кінцівками судна небезпечних об’єктів $€$ найбільш зручним так як вони найбільш часто використовуються в штурманської практиці судноводіння.

Ефективність роботи алгоритму (рис.2), який реалізує раніше пропонований спосіб [6,7], залежить в першу чергу від точності визначення географічних координат кінцівок судна $\mathrm{i}$ небезпечних об'єктів на ЕК, а також полярних координат, за допомогою яких виконується контроль безпечного проходу носу і корми судна відносно небезпечних об'єктів.

Точність визначення географічних координат кінцівок судна на ЕК в свою чергу залежить від точності спеціального режиму роботи ГНСC GPS і ГЛОНАСС, який в диференціальному режимі 3 імовірністю $\mathrm{P}=95 \%$ становить $\widehat{M}_{D G P S}= \pm 10$ м. Точність розташування на ЕК електронних позначок носу і корми судна та небезпечних об'єктів залежить від граничної точності масштабу карти, яка для масштабу $\mathrm{M}=1: 25000$ становить $\widehat{\mathrm{M}}_{\text {гтм }}= \pm 5 \mathrm{M}$.[8]. Гранична точність масштабу карти ( $\left.\widehat{\mathrm{M}}_{\text {гтм }}\right)$ в метрах наведена в таблиці 3.

Таблиця 3

Гранична точність масштабу карти.

\begin{tabular}{|c|c|c|c|c|c|c|c|}
\hline $\begin{array}{c}\text { Масштаб } \\
\text { карти }\end{array}$ & $1: 500000$ & $1: 200000$ & $1: 100000$ & $1: 50000$ & $1: 25000$ & $1: 10000$ & $1: 500$ \\
\hline$\widehat{M}_{\text {гтм }}$ & 100 & 40 & 20 & 10 & 5 & 2 & 0,1 \\
\hline
\end{tabular}


Розрахунок граничної точності визначення дистанцій $\widehat{M}_{D}$ до небезпечних об'єктів можна виконувати за формулою яка приведена нижче:

$$
\widehat{M}_{D}=\sqrt{\widehat{\mathrm{M}}_{\mathrm{TTM}}^{2}+\widehat{M}_{D G P S}^{2}}
$$

де: $-\widehat{M}_{D}-$ гранична точність визначення дистанції;

- $\widehat{M}_{D G P S}-$ гранична точність визначення місця судна за допомогою DGPS;

- $\widehat{\mathrm{M}}_{\text {гтм }}$-гранична точність масштабу ЕК.

Так, для ЕК масштабу M=1:25 000 згідно враження 3 гранична точність визначення дистанції становить $\widehat{M}_{D}= \pm 12,2 \mathrm{M}$., яка на порядок вище точності вимірювання відстаней за допомогою радіолокаційних станцій (РЛС).

Експериментальні дослідження, які були проведені шляхом комп'ютерного імітаціонного моделювання, підтвердили високу точність запропонованої моделі [6,7]. Високоточна координатна прив'язка кінця курсора з об'єктом, за результатами проведеного експерименту, що моделює автоматичне цифрове захоплення об'єктів, по точності вимірювання дистанцій в 28 разів, по точності вимірювання пеленгів в 5 разів перевищує точність вимірювань цих навігаційних параметрів за допомогою існуючего ручного візуального суміщення. Кінцеві результати експерименту, виконаного по 200 ітераціям для кожного способу вимірювання, при відстані між судном і навігаційним об'єктом (маяком) в 10 миль, наведені в таблиці 4.

СКП вимірювання пеленгів і дистанцій за результатами експерименту

Таблиця 4

\begin{tabular}{|c|c|c|c|c|c|c|}
\hline $\begin{array}{c}\text { Спосіб } \\
\text { вимірювання }\end{array}$ & \multicolumn{2}{|c|}{$\begin{array}{c}\text { Існуюче візуальне } \\
\text { ручне суміщення } \\
\text { позначек }\end{array}$} & \multicolumn{2}{|c|}{$\begin{array}{l}\text { Координатне ручне } \\
\text { суміщення позначек }\end{array}$} & \multicolumn{2}{|c|}{ За допомогою РЛС } \\
\hline СКП & $\Pi$ & Д & $\Pi$ & Д & $\Pi$ & Д \\
\hline вимірювання & $\pm 0,25^{\circ}$ & $\pm 95,9 \mathrm{M}$ & $\pm 0,05^{\circ}$ & $\pm 3,44 \mathrm{M}$ & $\pm 1,0^{\circ}$ & $\pm 141.3 \mathrm{M}$ \\
\hline
\end{tabular}

На підставі викладеного можна розраховувати на те, що при реалізації запропонованого алгоритму в практици судноводіння стане можливим вимірювати відстані від носу і корми великотоннажних суден і складів до навігаційних та інших небезпек в межах точності роботи спеціальних режимів ГНСС.

Розрахунок полярних координат проводиться рішенням системи 3 4-х рівнянь по високоточним формулам сферичної тригонометрії шляхом перетворення географічних координат носу $\left(\varphi_{\mathrm{H}}, \lambda_{\mathrm{H}}\right)$ і корми $\left(\varphi_{\mathrm{K}}, \lambda_{\mathrm{K}}\right)$ судна i координат небезпечного об'єкту $\left(\varphi_{\text {но }}, \lambda_{\text {но }}\right)$ по наведеним нижче формулам (4)

$$
\begin{gathered}
\cos \mathbf{D H}_{\mathbf{H}}=\sin \varphi \mathrm{H} \times \sin \varphi \mathrm{HO}+\cos \varphi \mathrm{H} \times \cos \varphi \mathrm{HO} \times \cos (\lambda \mathrm{HO}-\lambda \mathrm{H}) ; \\
\cos \mathbf{D}=\sin \varphi \mathrm{K} \times \sin \varphi \mathrm{HO}+\cos \varphi \mathrm{K} \times \cos \varphi \mathrm{HO} \times \cos \left(\lambda_{\mathrm{HO}}-\lambda \mathrm{K}\right) ; \\
\operatorname{ctg} \mathbf{H}_{\mathbf{H}}=\cos \varphi \mathrm{H} \times \operatorname{tg} \varphi \mathrm{HO} \times \operatorname{cosec}\left(\lambda_{\mathrm{HO}}-\lambda_{\mathrm{H}}\right)-\sin \varphi \mathrm{H} \times \operatorname{ctg}\left(\lambda_{\mathrm{HO}}-\lambda_{\mathrm{H}}\right) ; \\
\operatorname{ctg} \Pi \mathbf{\kappa}=\cos \varphi \mathrm{K} \times \operatorname{tg} \varphi \mathrm{HO} \times \operatorname{cosec}\left(\lambda_{\mathrm{HO}}-\lambda \mathrm{K}\right)-\sin \varphi \mathrm{K} \times \operatorname{ctg}\left(\lambda_{\mathrm{HO}}-\lambda \mathrm{K}\right) .
\end{gathered}
$$

Алгоритм роботи ECDIS , який реалізує корисну модель для запропонованого способу, представлений на рис. 2. Застосування формул сферичної тригонометрії для розрахунку дистанцій і пеленгів на небезпечні об'єкти є допустимим в силу незначних відстаней на яких пропонується використовувати даний алгоритм, тому можна умовно прийняти ортодроміческій пеленг рівним локсодроміческому (Порт. = Плок.). 


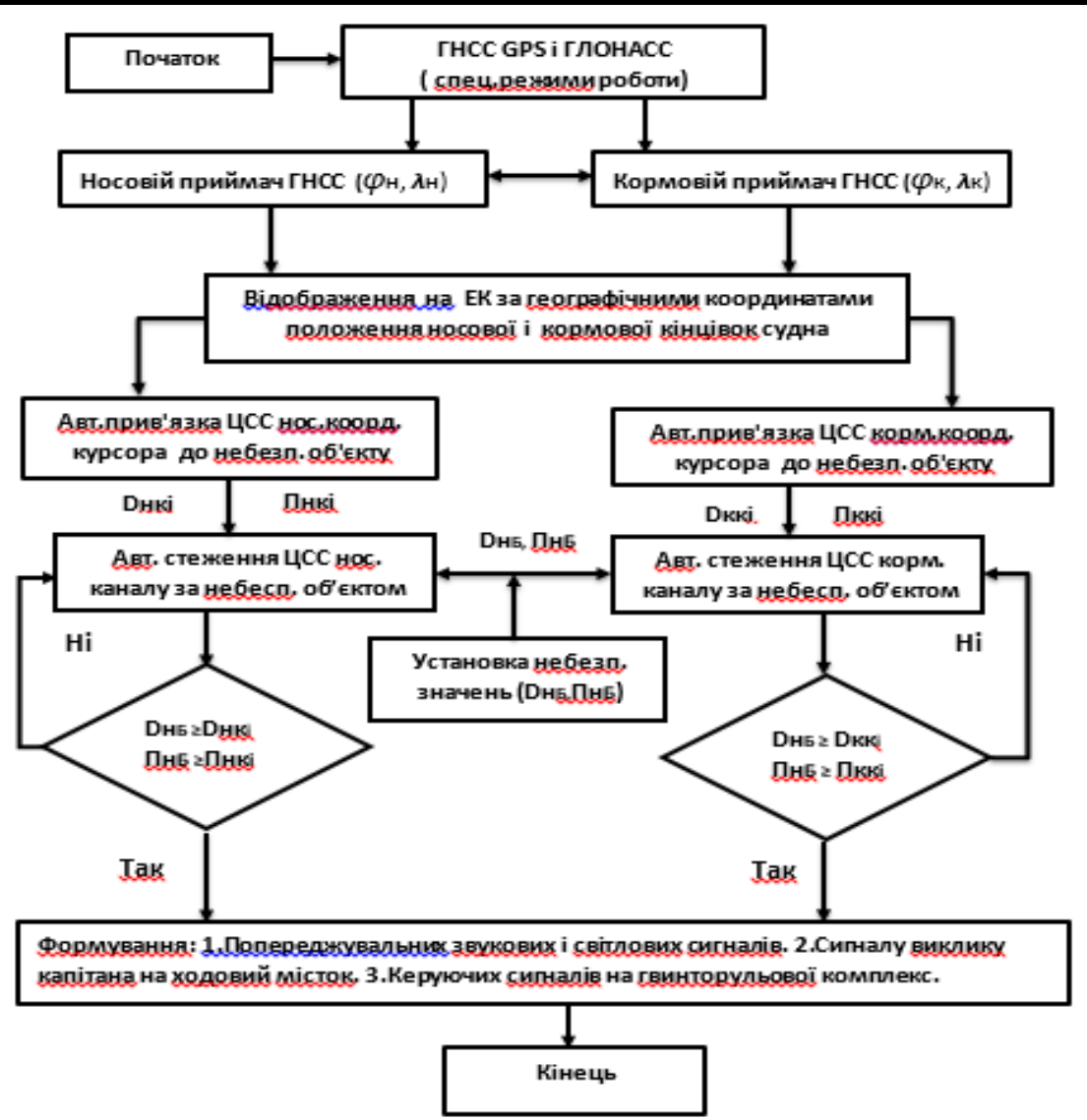

Рис. 2. Алгоритм роботи ECDIS

Пропонований алгоритм може бути застосований при вирішенні таких високоточних завдань судноводіння як:

- прогнозування місцезнаходження судна (складу) на траєкторії руху з урахуванням напрямків і відстаней до навігаційних об'єктів (небезпек) та визначення інерційногальмівних характеристик суден, яки безперервно змінюються; - визначення відстаней до навігаційних орієнтирів, підводних рифів , банок і затонулих об'єктів та напрямків на них від носу i корми судна або складу; - здійснення контролю за сумарним зносом суден від вітру і течіі при плаванні по фарватерам, каналам і річкам для виведення їх на ось суднового ходу і точку початку повороту;

- забезпечення підходу судна до причалу по траєкторії, яка задається пеленгом зближення носу судна $з$ коренем причалу і контролю дистанції до кореня і торця причалу від кінцівок судна одночасно в процесі його швартування.

Надійність роботи даного алгоритму забезпечується високими точностними характеристиками спеціальних режимів ГНСС і високою ймовірністю їх безвідмовної роботи.

\section{ЛIТЕРАТУРА}

1. dKart Navigator 9000. Керівництво користувача, 2011.

2. NAVI - SAILOR 3000. Керівництво користувача, 2002.

3. ANNUAL OVERVIEW OF MARINE CASUALTIES AND INCIDENTS 2016. // European Maritime Safety Agency. - 2016. - C. 119.

4. Навігаційне забеспечення мореплавства: виробничо-практичний посібник. /С.В.Симоненко, М.Ф.Голодов.// -К.: ДУ «Держгідрографія», 2014. - С.26-27.

5. Давидов В.С. Математична модель забеспечення безпеки плавання буксирніх складів, що штовхаються, на річках i в прибережній морській зоні. /Косяковський А.В., Давидов В.С., Овчіннікова А.І./ЦЦНДІ озброєння та військової техніки Збройних Сил України. Збірник наукових праць. Вип.3(23) 2019.- С.117-122. 
6. Давидов В.С., Овчіннікова А.І. Свідоцтво про реєстрацію авторського права на твір «Способ контроля местоположения крупногабаритних судов и составов на траектории движения путем использования координатного курсора ЭКНИС в режиме высокоточного угломерно-дальномерного устройства», № 88994 від. 28.05.2019p.

7. Давидов В.С. Овчіннікова А.І. Спосіб контролю місце розташування великогабаритних суден і складів на траєкторії руху шляхом використання координатного курсора ЕКНІС в режимі високоточного кутомірно-далекомірного пристрою. ХДМА, Сборник научных трудов «Науковий вісник», вип.№1(18)- 2018, С.4-9;

8. Давыдов В.С. Повышение безопасности эксплуатации крупнотоннажных судов путем оптимизации использования ЭКНИС./Давыдов В.С., Демичев В.В., Кожухаренко Р.В., Овчинникова А.И. //Водний транспорт, вып.1(24), К. : КГАВТ,- 2016, С.20-24.

9. Богом'я В.І., Давидов В.С., Кожухаренко Р.В., Демічев В.В. Свідоцтво про реєстрацію авторського права на твір «Способ контроля местоположения крупнотоннажных морских судов на траектории движения путем использования системы приемников ГНСС сопряженных с ЭКНИС», № 6083 від 6.05.2015.

10. Богомья В.И. Анализ некоторых эксплуатационных свойств современных крупнотоннажных судов, методов и систем их обеспечения при плавании в стесненных условиях. /Богомья В.И., Давыдов В.С., Кожухаренко Р.В.//Збірник наукових праць«Водний транспорт».-К.,КДАВТ,2014-вип.3(21).-С.23-31.

11. Богомья В.И. Пути повышения эффективности обеспечения безопасности плавания крупнотоннажных судов в сложных навигационных условиях./Богомья В.И., Давыдов В.С., Кожухаренко Р.В., Демичев В.В. //Збірник наукових праць-«Водний транспорт».К.,КДАВТ, 2014-вип.1(19)-С. 66-70.

\section{Bogomya V.I., Davydov V.S., Doronin V.V., Kudryavtsev V.G. \\ AN ALGORITHM FOR AUTOMATED CONTROL OF THE POSITION OF THE EXTREMITIES OF SHIPS AND WAREHOUSES ON THE TRAJECTORY OF MOVEMENT BY MEANS OF ECDIS}

The article deals with the algorithm of control of the position of ships and warehouses on the trajectory, which solves the problem of automated high-precision control of the position of the extremities of ships and warehouses on the trajectory of motion by means of ESDIS. The algorithm of automated control of the position of the extremities of ships and warehouses on the trajectory, using the ECDIS coordinate cursor as a high-precision angular-rangefinder device, allows, when placed in the nose and stern of the vessel antennas GNSS receivers, to form on the EC their electronic markers with their coordinate cursors. These cursors can be used, when implemented automatically, using digital tracing systems (to the full coincidence of coordinate codes) and accompanying their finely controlled objects (geographical coordinates of which are in the electronic database) for high-precision automatic measurement of bearings and distances to underwater and of surface hazards in on-line modes for the purpose of controlling their position using the extremities of ships and warehouses relative to hazards with an accuracy comparable to the accuracy of GNSS operation in special ymah. Experimental studies, which were carried out by computer simulation, confirmed the high expected accuracy of the proposed algorithm, which is based on the same method.

Keywords: algorithm, vessel, method, automated control, coordinate cursor, bearing, distance, navigation safety, trajectory. 